\title{
Customers' Perception Towards Mobile Banking with Reference to Chennai City
}

\author{
R. Purushothaman
}

\begin{abstract}
India is a developing and leading country in the field of technology. We are facing the fourth industrial revolution. In this era, technology advancement plays a crucial role in all the part of industries. In banking sectors also technology plays an important role. Due to the technology advancement traditional banking operations are changing to modern banking methodologies. One of the most important modern banking methods is Mobile Banking or M-Banking. This study attempts to fathom the customers' perception towards M-Banking with reference to Chennai city. The aim of the study is to know the reasons for using M-Banking services by the respondents and to identify the level of awareness of the respondents. In the sample survey method, questionnaire technique is used to collect the primary data. The sample size is 60 banking customers in Chennai city. After analysing the data, it is observed that banks and government need to motivate and create awareness among the customers to widely use M-Banking services.
\end{abstract}

Keywords: Banking customers, Technology, Mobile Banking and Customers Perception.

\section{INTRODUCTION}

$\mathrm{T}$ echnology advancement is more vital in all segments of industries. Hence, all the segments should adopt technological changes to sustain and achieve in their filed. In no doubt, the banking sectors are also changing from traditional methods of banking operation to modern methods of operation. In India, most of the banks are adopting modern banking services like online banking, automated depositing machine, automated pass book entry machine, mobile banking or M-Banking etc., M-Banking is one of the major elements of modern banking services. M-Banking means undertaking banking operation through Mobile device.

M-Banking services comprises of balance enquiry, m-pass book, m-statement, fund transfer, utility bill payment, ATM locator, SMS services etc., Even though, most of the people in India are using smart phones, crowd in bank and time spent in banks to access banking services is not reduced. In this study, the level of awareness on using M-Banking Services and the reasons for using M-Banking services are analysed.

Revised Manuscript Received on December 05, 2019.

* Correspondence Author

Dr. R. Purushothaman*, Assistant Professor, PG \& Research Department of Commerce, Guru Nanak College (Autonomous), Chennai, India.

\section{OBJECTIVES OF THE STUDY}

1. To study the socio-economic profile of the respondents.

2. To know the reasons for using M-Banking services by the respondents.

3. To identify the level of awareness of the respondents about M-Banking.

\section{RESEARCH METHODOLOGY}

Population of the study: Banking customers in Chennai city

Method of Data Collection: Sample survey method. Convenient sampling method was adopted.

Technique of Data Collection: Questionnaire technique.

Sample Size: 60 respondents from Chennai city

Types of Data: Primary and secondary data.

\section{A. Hypotheses}

- There is no significant difference in the ranking of reasons for using M-Banking services.

- There is no significant association between Socio Economic profile of the respondents and overall awareness level of Mobile banking services.

B. Statistical Tools Applied

- Percentage analysis

- Mean

- Friedman's Test

- Chi-square Analysis

\section{LIMITATIONS}

1. The study is limited to 60 banking customers.

2. The survey is conducted in Chennai city only.

3. This study confines only ten reasons for using M-Banking services.

\section{REVIEW OF LITERATURE:}

Zaman et al (2011) study analysed the reasons for using M-Banking services for trustworthiness followed by handiness followed by promptness and security.

Yesodha Devi et al (2011) concluded that there is no association between education and the level of awareness on M- Banking usage.

Amola bhatt (2016), in his article found that updated user friendly technology is the

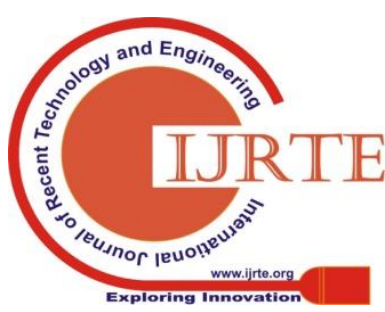


prime motivational factors for using M-Banking.

Mahammad sakheer (2017) examined that the leading reason for non-usage of internet banking in mobiles are due to low literacy rate in Belthangady taluk compared to other cities . Amsaveni and Kanagarathinam (2017) stated that the awareness level of respondents towards internet banking services offered at free of cost has secured first rank.

Ankita Pathak and Sunil Mishra (2019), in their research Article, found that the perception of the consumer influenced by ease to use M-Banking services is the prime factor.

\section{ANALYSIS AND INTERPRETATION}

Table -1: Socio - Economic Profile of the respondents

\begin{tabular}{|c|c|c|}
\hline $\begin{array}{c}\text { Socio-Economic Factors and Personal } \\
\text { Variables }\end{array}$ & Frequency & $\%$ \\
\hline \multicolumn{3}{|l|}{ Age (in year) } \\
\hline $18-30$ & 37 & 61.7 \\
\hline $31-40$ & 12 & 20 \\
\hline$>40$ & 11 & 18.3 \\
\hline \multicolumn{3}{|l|}{ Gender } \\
\hline Male & 41 & 68.3 \\
\hline Female & 19 & 31.7 \\
\hline \multicolumn{3}{|l|}{ Marital Status } \\
\hline Single & 30 & 50 \\
\hline Married & 30 & 50 \\
\hline \multicolumn{3}{|l|}{ Educational Qualification } \\
\hline No Schooling & 0 & 0 \\
\hline Upto HSC & 8 & 13.3 \\
\hline Graduate & 36 & 60 \\
\hline Professional & 11 & 18.3 \\
\hline Others & 5 & 8.3 \\
\hline \multicolumn{3}{|l|}{ Occupation } \\
\hline Students & 7 & 11.7 \\
\hline PVT. Employed & 27 & 45 \\
\hline Govt. Employed & 4 & 6.7 \\
\hline Business & 11 & 18.3 \\
\hline Others & 11 & 18.3 \\
\hline \multicolumn{3}{|l|}{ Family Pattern } \\
\hline Nuclear Family & 41 & 68.3 \\
\hline Joint Family & 19 & 31.7 \\
\hline \multicolumn{3}{|l|}{ Annual Income (Rs.) } \\
\hline Upto $2,00,000$ & 22 & 36.7 \\
\hline $2,00,001$ to $4,00,000$ & 15 & 25 \\
\hline $4,00,001$ to $6,00,000$ & 11 & 18.3 \\
\hline Above $6,00,000$ & 12 & 20 \\
\hline
\end{tabular}

Source: Primary data

The majority of the respondents $(61.7 \%)$ are in the age group of 18-30 years. Majority of respondents, 68.3 per cent are male. Considering the marital status of the respondents that are equal at $50 \%$ each. A Majority of the respondents $(60 \%)$ are Graduates and maximum of respondents (45\%) are from PVT. employed category. Majority of the respondents $(68.3 \%)$ are in the nuclear family. As regards annual income, a maximum of the respondents $(36.7 \%)$ have income upto Rs.2, 00,000.
Table - 2: Banking Details of the respondents

\begin{tabular}{|c|c|c|c|}
\hline $\begin{array}{l}\text { Banking } \\
\text { Variables }\end{array}$ & Banking Details & Frequency & Percent \\
\hline \multirow{3}{*}{ Types of Bank } & Public & 12 & 20 \\
\hline & Private & 30 & 50 \\
\hline & Both & 18 & 30 \\
\hline \multirow{6}{*}{$\begin{array}{l}\text { Number of hours } \\
\text { using mobile } \\
\text { phone per day } \\
\text { (in hours) }\end{array}$} & Upto 1 & 7 & 11.7 \\
\hline & $2-3$ & 14 & 23.3 \\
\hline & $4-6$ & 19 & 31.7 \\
\hline & $7-9$ & 10 & 16.7 \\
\hline & $9-12$ & 6 & 10 \\
\hline & $>12$ & 4 & 6.7 \\
\hline \multirow{3}{*}{$\begin{array}{l}\text { Years of using } \\
\text { mobile banking }\end{array}$} & Upto 1 years & 26 & 43.3 \\
\hline & 2 years to 4 years & 27 & 45 \\
\hline & Above 4 years & 7 & 11.7 \\
\hline \multirow{4}{*}{$\begin{array}{l}\text { Frequency of using } \\
\text { Mobile Banking }\end{array}$} & Daily & 18 & 30 \\
\hline & Weekly & 19 & 31.7 \\
\hline & Monthly & 13 & 21.7 \\
\hline & Rarely & 10 & 16.7 \\
\hline
\end{tabular}

Source: Primary Data

With respect to banking details, Majority of the respondents $(50 \%)$ are holding account in private bank and maximum of the respondents $(31.7 \%)$ use mobile phone 4-6 hours a day. Maximum of the respondents (45\%) are using M-Banking services for2-4 years and maximum of the respondents $(31.7 \%)$ are using M-Banking services on weekly basis.

Table - 3: Mean Rank for Reasons for using M-Banking Services - Friedman's Test

\begin{tabular}{|l|c|c|}
\hline Reasons for using M-Banking Services & $\begin{array}{c}\text { Mean } \\
\text { Rank }\end{array}$ & $\begin{array}{c}\text { Rank } \\
\text { Order }\end{array}$ \\
\hline Any time (24/7) and Everywhere usage & 3.12 & 1 \\
\hline Saving More time & 3.23 & 2 \\
\hline Convenience & 3.55 & 3 \\
\hline Familiar in smart Phone usage & 4.82 & 4 \\
\hline Safety and Security & 5.14 & 5 \\
\hline Spending more time in Bank & 5.57 & 6 \\
\hline Customer friendly & 5.97 & 7 \\
\hline Paperless & 6.15 & 8 \\
\hline Less number of bank branches & 7.78 & 9 \\
\hline Others & 9.68 & 10 \\
\hline
\end{tabular}

Source: Primary data

The reasons for using M-Banking Services are ranked in the above table using Friedman's test from the responses given by the respondents. 'Any time (24/7) and Everywhere usage' takes the lead with the mean value of 3.12, followed by 'Saving more time', 'Convenience', 'Familiar in Smart Phone usage', 'Safety and Security', 'Spending more time in bank', 'Customer friendly', 'papers less' and 'Less number of bank branches' have been ranked second, third, fourth, fifth, sixth, seventh, eighth and ninth respectively. 'For other reasons' takes the last rank. Hence, it is proved that 'any time $(24 / 7)$ and everywhere usage' is the prime reason for using M-Banking.

Published By:

Blue Eyes Intelligence Engineering 


\section{Test of Hypothesis}

\section{Hypothesis 1}

H0: There is no significant difference among the ranking of reasons for using M-Banking Services.

H1: There is a significant difference among the ranking of reasons for using M-Banking Services.

Table - 4: Test Statistics - Friedman's Test

\begin{tabular}{|c|c|c|}
\hline Chi - Square & Df & Asymp. Sig. \\
\hline 252.265 & 9 & .000 \\
\hline
\end{tabular}

Since the significance level 0.000 is lesser than 0.05 (p < $0.05), \mathrm{H} 0$ is rejected and $\mathrm{H} 1$ is accepted. Therefore, there is a significant difference among the ranking ofreasons for using M-Banking services at five per cent level of significance.

Table - 5: Respondents Awareness about M-Banking Services

\begin{tabular}{|l|c|c|}
\hline \multicolumn{1}{|c|}{ Mobile Banking Services } & $\begin{array}{c}\text { Yes } \\
\text { (In \%) }\end{array}$ & $\begin{array}{c}\text { No } \\
\text { (In \%) }\end{array}$ \\
\hline SMS Banking Services & 95 & 5 \\
\hline Accounts Balance enquiry & 98.3 & 1.7 \\
\hline e-pass book views or download & 71.7 & 28.3 \\
\hline Cheque book request & 73.3 & 26.7 \\
\hline Cheque status enquiry & 68.3 & 31.7 \\
\hline Fund transfer & 98.3 & 1.7 \\
\hline Bill Payments (EB, Mobile recharge etc.) & 96.7 & 3.3 \\
\hline Access of account details through e-mail & 78.3 & 21.7 \\
\hline Debit card block or unblock & 81.7 & 18.3 \\
\hline Information about interest rate and other updates & 68.3 & 31.7 \\
\hline Source: Primary data & &
\end{tabular}

An analysis of above table shows that, a majority of the respondents ( 98.3 per cent) are aware of account balance enquiry and fund transfer mobile banking services followed by bill payments with 96.7 per cent awareness among the respondents. 95 per cent are aware that SMS banking services, 81.7 per cent are aware that debit card block/ unblock, 78.3 per cent are aware about an access of $\mathrm{A} / \mathrm{c}$ details through e-mail, 73.3 per cent are aware about cheque book request service, 71.7 per cent are aware that e-pass book views or download and 68.3 per cent are aware about cheque status enquiry and information about interest rate and other updates. Hence, it is concluded that the most of the respondents are aware about the account balance enquiry and fund transfer mobile banking services than other services.

Table 6: Overall awareness level of the respondents about M-Banking Services

\begin{tabular}{|c|c|c|}
\hline Awareness Level & Frequency & Percent \\
\hline Low level & 3 & 5.0 \\
\hline Average level & 29 & 48.3 \\
\hline High level & 28 & 40.7 \\
\hline
\end{tabular}

The above table shows that the maximum of the respondents $(48.3 \%)$ have an average level of awareness followed by $40.7 \%$ respondents have a high level of
Source: Primary data

awareness about M-Banking services. Only minimum numbers of respondents are in low level of awareness on M-Banking.

\section{Hypothesis 2}

H0: There is no significant association between Socio Economic profile of the respondents and overall awareness level about Mobile banking services.

H1: There is a significant association between Socio Economic profile of the respondents and overall awareness level about Mobile banking services.

Table - 7: Chi-Square Test

\begin{tabular}{|l|c|c|c|}
\hline \multicolumn{1}{|c|}{ Socio Economic Factors } & Value & Df & $\begin{array}{c}\text { Asymp. Sig. } \\
\text { (2-sided) }\end{array}$ \\
\hline Age group & 4.798 & 4 & 0.309 \\
\hline Gender & 0.12 & 2 & 0.994 \\
\hline Marital Status & 0.368 & 2 & 0.832 \\
\hline Educational Qualification & 8.940 & 6 & 0.177 \\
\hline Occupation & 12.445 & 8 & 0.132 \\
\hline Family Pattern & 3.239 & 2 & 0.198 \\
\hline Income Group & 7.119 & 6 & 0.310 \\
\hline
\end{tabular}

Chi square test shows that the significance values are greater than $0.05(\mathrm{P}>0.05)$. Hence, alternative hypothesis is rejected. It is therefore inferred that there is no significant association between socio economic profile of the respondents and overall awareness level about mobile banking services.

\section{FINDINGS}

Socio-Economic Profile: The majority of the respondents $(61.7 \%)$ are in the age group of $18-30$ years, 68.3 per cent are male, $50 \%$ of the respondents are single and $50 \%$ of the respondents are married, $60 \%$ of the respondents are Graduates, $45 \%$ of the respondents are from PVT. Employed, $68.3 \%$ of the respondents are in the nuclear family and $36.7 \%$ of the respondents have an annual income upto Rs.2, 00,000 .

Banking Details: Majority of the respondents (50\%) are holding account in private bank and maximum of the respondents $(31.7 \%)$ use mobile phone 4-6 hours a day. Maximum of the respondents $(45 \%)$ are using mobile banking services for 2-4 years and maximum of the respondents $(31.7 \%)$ are using mobile banking services on weekly basis.

Reasons for using M-Banking Services: 'Any time (24/7) and Anywhere usage' is the prime reason for using M-Banking services.

Overall awareness level: This study shows that maximum of the respondents (48.3\%) have an average level of awareness of M-Banking.

Published By:

Blue Eyes Intelligence Engineering 


\section{SUGGESTIONS}

- This study found that the majority of the respondents are using M-Banking services fall under 18-30 years of age group i.e., youngsters. So, bankers should create awareness about M-Banking services and their advantages to the customers of other age group

- This study found that the majority of the respondents are holding accounts in private sector banks, hence the government should consider opening new public sectors banks (and new branches for existing PSB's) instead of merging banks which will also create employment opportunities in banking sectors and also provides services to the customers at low cost.

- This study clarifies that the maximum of the respondents have an average level of awareness in using M-Banking services. So, the customers should learn to use the M-Banking services.

- This study shows that the least percentage of respondents are aware of updates from banks like interest rate, loan offers, Government schemes etc., So, customers should know more about banking updates through M-Banking services and get benefited.

\section{CONCLUSION}

The research brings out certain characteristics of the banking customers in Chennai city. M-Banking plays a vital role among the banking customers. Without knowing mobile banking services, customer needs to spend more time in their busy schedule. There are various reasons for using M-Banking services, in this study it examines that the prime reasons for using M-Banking is 'anytime and everywhere usage' followed by convenience and saving more time. It was also found that customers are having an average level of awareness about M-Banking services. So, this study suggests customers to learn to unlearn and learn to relearn the technology development in banking sectors.

\section{REFERENCES}

1. Zaman K, Adullah B.O, Sultan N and Bibin (2011), "Customer perception towards Online Banking services: Empirical Evidence from Pakitan", Journal of Internet Banking and Commerce, Vol.(16), Issue No:2, pp.3-12.

2. Yesodha devi, Jancy sebastina and Kanchana (2011), "A study on customer awareness, opinion, reasons for opting mobile banking", International journal of multidisciplinary research, Vol. (1), Issue No:7, p.233.

3. Amola bhatt (2016), “A study on factors affecting customer's adoption of M-Banking services”, Journal of Internet Banking and Commerce, Vol.(1), pp.1-22.

4. Mahammad sakheer (2017), "Consumer awareness and usage of E-Banking transactions through mobile phones-A study with reference to Belthangady Taluk", Journal of International conference of emerging trends in engineering, technology, science and management, ICETETSM-17, p.345.

5. Amsaveni and Kanagarathinam (2017),"A study on consumer awareness of E-Banking services in public sector banks in coimbatore district", IJARIIE, Vol.(3), Issue No:2, p.912

6. Ankita Pathak, sunil Mishra (2019), "Consumer behavior and attitude towards mobile banking: An empirical analysis", International Journal of Innovative Technology and Exploring Engineering, Vol.(8), Issue No:6S, p.497.

\section{AUTHOR PROFILE}

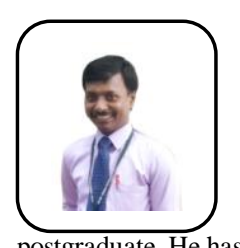
published several papers in leading international and national conferences. He has acted as an organizing committee member for a international conference and has good exposure in the academic environment. 